\title{
A Study of Landslide Areas Mitigation and Adaptation in Palupuah Subdistrict, Agam Regency, West Sumatra Province, Indonesia
}

\author{
Olivia Oktorie \\ Master Graduate of Geography Education \\ Faculty of Social Sciences, Universitas Negeri Padang \\ email : ochy.oliviaoktorie@gmail.com
}

\begin{abstract}
The purpose of this research was to determine the alternative policies of landslide area mitigation and adaptation in Palupuah Subdistrict, Agam Regency, West Sumatra Province, Indonesia. This research was descriptive research using mixed method. The data collection used purposive sampling by adapting the sample to criteria. The samples were Palupuah Subdistrict government agencies (the Department of Social, the Head of Palupuah Subdistrict, National Disaster Management Agency), the experts, and the society leaders of Palupuah Subdistrict. The results and discussion of the alternative policies of landslide area mitigation in Palupuah Subdistrict, Agam Regency, West Sumatra Province, Indonesia are: (1) conducting the settlements management in areas with landslides risk of the greatest weight rated $(0,795),(2)$ strengthening the slope vegetatively (0.792), (3) strengthening the slope mechanically (0.769), and (4) developing land allotment landslides based (0.750). The alternative policies of landslide area adaptation in Palupuah Subdistrict, Agam Regency, West Sumatra Province, Indonesia are: (1) avoiding building houses in the steep slopes area, (2) performing the agricultural pattern landslide mitigation based, (3) creating the sewerage in the water cycle area, and (4) making the rules based on the local wisdoms that respond to the landslide.
\end{abstract}

Keywords: Landslide, Mitigation, Adaptation

\section{Introduction}

Natural disasters are the natural events caused by natural processes, both of which occurred by nature itself or initiated by human actions, which pose dangers and risks to human life both to the property and lives. Characteristics of natural disasters are determined by the state of the physical environment such as climate, topography, geology, soil, water, land use, and human activity. Geologically, Indonesia has always experienced natural disasters which tend to increase over time both the type and frequency (Hermon and Triyatno 2005). Law No. 24 of 2007 on Disaster Management Article 2 Paragraph 9 states that mitigation is a series of efforts to reduce disaster risk through physical development, awareness or increase the ability of society to cope with disasters. Mitigation of landslide in principle aims to minimize the impact of the disaster. Therefore, the early disaster warnings are very important.

Natural disasters can strike suddenly or through a process which takes place slowly. The center for Volcanology and Geological Hazard Mitigation (PVMBG 2009) states that landslide is the movement of slope forming material in form of rocks, soil or mixed material which move down or off the slopes. The process of landslide can be initiated by the water which soaked into the soil which will add weight to the ground. If the water that penetrates to the watertight lining, it will act as the sliding plane, the ground becomes slippery and soil weathering on it will move to follow the slope and off the slopes. In this condition, heavy rainfall or flooding may lead to landslides. According to Hary (2012), many factors such as geological and hydrological conditions, topography, climate, and climate change affect the stability of the slope which 
resulted in a landslide. Natural causes that destabilize slopes, for example: weathering, heavy rain, or the not heavy but long rain, the soft lining, and others.

Landslide impact is local (as opposed to earthquakes and volcanic eruptions). However, it occurs often and can be fatal to because it happens suddenly. Disaster Statistics in Indonesia from January to August 2014 (National Disaster Management Agency 2014), states that the number of landslides were: 972 times, 374 dead and missing people, 1.764.227 suffered and evacuated victims and 39823 damaged houses. Landslides during August 2014 were 20 times and causing 8 deaths, 3 injured victims, 671 evacuated victims, 35 damaged houses, and 5 damaged public facilities.

\section{Method}

The research was conducted in the District Palupuh one sub-district located in Palupuah Subdistrict, Agam Regency, West Sumatra Province, Indonesia. This research used qualitative descriptive method that aims to describe and convey the findings in the research. The samples were Palupuah Subdistrict government agencies (the Department of Social, the Head of Palupuah Subdistrict, National Disaster Management Agency), the experts, and the society leaders of Palupuah Subdistrict. The data analysis to formulate alternatives policy was done by using AHP (Analythical Hierarchy Process)

\section{Results and Discussion}

Palupuh Subdistrict is one of the subdistricts located in Agam Regency, which was once a part of Tilatang Kamang Subdistrict. With the development of the region and the increasing service needs of the society, then the society of Palupuh wanted to form the Representative Subdistrict for the distance to the capital of Tilatang Kamang which was far from Palupuh. Judging from administrative boundaries, the Palupuh Subdistrict consists of 4 Kenagarian, namely Nagari Koto Rantang, Nagari Pasia Laweh, Nagari Nan Tujuah, and Nagari Pagadih, and is divided into several jorong. Palupuh Subdistrict has an area of 237.08 $\mathrm{km} 2$ and is located 756 meters above sea level with the population of 13.044 inhabitants with an average density of 55.02 people/km2 (Agam CBS 2010). Palupuh Subdistrict is layout located astronomically between 0 01'56" SL until 0 015'40" SL and 100 012'7 " ET until 100022'43" ET, while administratively, Palupuh Subdistrict boundaries are as follows:

North : Pasaman Regency and 50 Kota Regency

East : Pasaman Regency and 50 Kota Regency

West : Palembayan Subdistrict

South : 50 Kota Regency and Tilatang Kamang Subdistrict

The Alternative Policies of Landslide Area Mitigation and Adaptation in Palupuah Subdistrict, Agam Regency

Based on the results of research, the alternative policies of landslide area mitigation and adaptation in Palupuah Subdistrict, Agam Regency were obtained in terms of the three aspects: (1) the characteristics of the prone to landslides area, (2) the dangers level of landslides, and (3) the risks level of landslides. The details of the alternative policies of landslide area mitigation and adaptation in Palupuah Subdistrict, Agam Regency can be seen in Figure 1. 


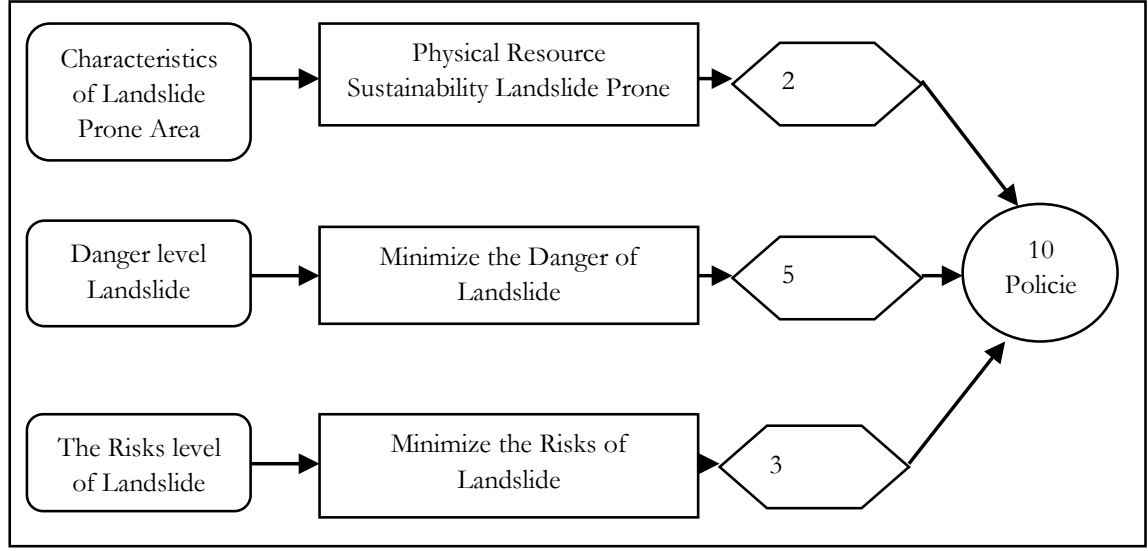

Figure 1. The Alternative Policies of Landslide Area Mitigation and Adaptation in Palupuah Subdistrict, Agam Regency

The alternative policies of landslide area mitigation and adaptation in Palupuah Subdistrict, Agam Regency are as follows: (1) Performing friendly land reclamation landslides, (2) Increasing the land stability, (3) Formulating the zoning at each dangers level of landslides, (4) Strengthening the slope mechanically, (5) Strengthening the slope vegetatively, (6) Developing the land allotment landslides based, (7) Socializing the prone to landslides area, (8) Formulating the zoning landslide risk, (9) Setting up the settlements in the prone to landslides area, and (10) Doing relocation

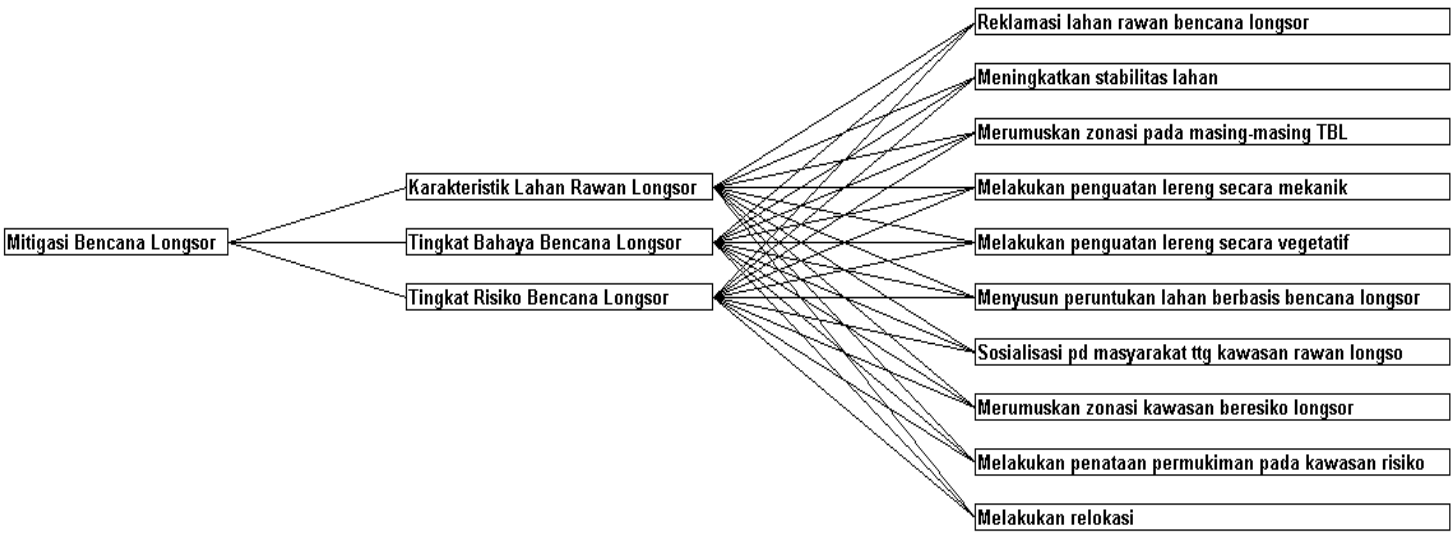

Figure 2. Hierarchical Framework of Alternative Policies of Landslide Area Mitigation and Adaptation in Palupuah Subdistrict, Agam Regency

The Priorities of the Alternative Policies of Landslide Area Mitigation and Adaptation in Palupuah Subdistrict, Agam Regency

The selection policy priorities were based on the amount of weight (eigen values) on each alternative policies. The analysis of selection policy priorities was done if the criteria pairs consistency ratio value $<0.1$. The formulation of the policy priorities of the alternative policies of landslide area mitigation and adaptation in Palupuah Subdistrict, Agam Regency are as follows: (1) conducting the settlements management in areas with landslides risk of the greatest weight rated $(0,795)$, (2) strengthening the slope vegetatively (0.792), (3) strengthening the slope mechanically (0.769), and (4) developing land allotment landslides based (0.750). The results of the policy priorities analysis are listed in Figure 3. 


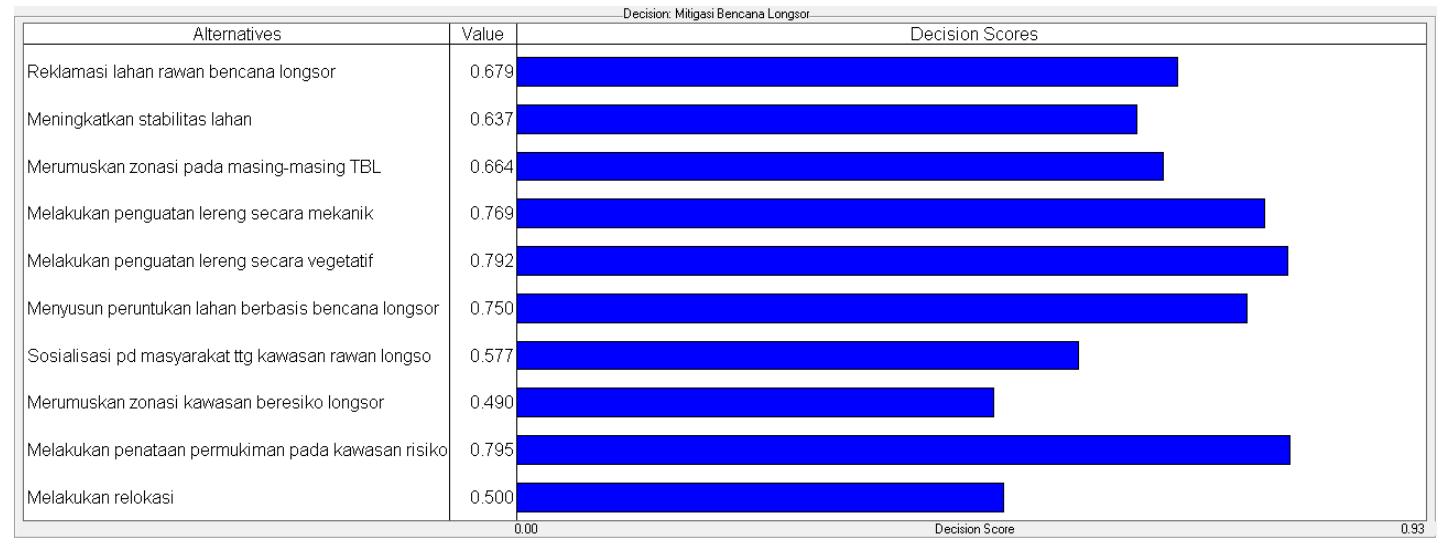

Figure 4. The Priorities of the Alternative Policies of Landslide Area Mitigation and Adaptation in Palupuah Subdistrict, Agam Regency

The four alternative policy priorities offered are:

1. Conducting the settlements management in areas with landslides risk

2. Strengthening the slope vegetatively

3. Strengthening the slope mechanically

4. Developing land allotment landslides based

\section{The Implementation of the Alternative Policies of Landslide Area Mitigation and Adaptation in Palupuah Subdistrict, Agam Regency}

The research conducted had discussed the ideas of all stakeholders in relation to the alternative policies of landslide area mitigation and adaptation in Palupuah Subdistrict, Agam Regency, West Sumatra Province, Indonesia. The discussions and interviews were focused on three topics, namely: (1) the factors to be considered in the implementation of the four policies, (2) the constraints that may be encountered in the implementation of the four policies, and (3) the strategic steps that must be done in the implementation of the four policies. Furthermore, in the questionnaire spread, the feedback obtained the physical environmental, social, cultural, and institutional factors directives in the implementation of the alternative policies of landslide area mitigation and adaptation in Palupuah Subdistrict, Agam Regency.

In the planning stage, it is necessary to design the landslide mitigation program that is environmentally sound, consider the characteristics of the region based on the dangers and risks of level zones through spatial approach, so that the use of land is accordance to the land suitability based in Palupuah Subdistrict, Agam Regency. In the implementation stage, it is necessary not to cause the physical damages the environment, manage and use the land needs to be based on landslides, and control the land use. The socio-cultural factors that need to be considered in the implementation of the alternative policies are use the social cultural wisdoms of Palupuah Subdistrict, Agam Regency of society, empower of the local society and indigenous rights which give very dominant influence on the land use in Palupuah Subdistrict, Agam Regency. The institutional factors that need to be considered in the implementation of the alternative policies are is the synchronization and synergy between existing institutions, at the district, subdistrict, and village level., increase the performance of LKAAM (Lembaga Kerapatan Adat Alam Minangkabau) in a landslide mitigation process, encourage the active participation of NGOs (Non Governmental Organization) and universities to play role in monitoring landslide mitigation. The implementation strategies were designed based on the characteristics of each policy alternative by considering the physical environmental, social, cultural, and institutional. Based on these factors, the implementation strategies were discussed through in- 
depth interviews with all stakeholders to ensure successful the implementation of the alternative policies of landslide area mitigation and adaptation in Palupuah Subdistrict, Agam Regency. The details of the implementation of the alternative policy priorities of landslide area mitigation and adaptation in Palupuah Subdistrict, Agam Regency are outlined based on the results of AHP.

\section{The Arrangement of Settlements in Landslide Risk Areas in Palupuah Subdistrict, Agam Regency}

The arrangement of the settlements in areas with landslides risk require efforts to control land use oriented to the application of the law firmly. However, it is very difficult to implement in due to the difficulty of determining the exact mechanism in the effort to organize the settlement. Various factors need to be considered for the implementation of the policies are: (1) the social and cultural conditions of Palupuah Subdistrict, Agam Regency especially in land proprietary and knowledge of spatial settlement, (2) the limits of the areas with landslides risk associated with land proprietary, and (3) economic activities of Palupuah Subdistrict, Agam Regency which are agriculturally oriented. The strategic steps that need to be done in the implementation of the policies are: (1) conducting the study of the supervision mechanisms (monitoring, reporting, and evaluation), policing, and the operational sanctioning, and providing the guidance of the implementation for agencies in the district, (2) imposing high taxes on areas with landslides risk as well as areas that are not intended for settlements, (3) empowering the society in the supervisory activities and control of settlements in areas with landslides risk, and (4) having the commitment of government subdistrict and district as well as LKAAM for the implementation of firm and consistent legal sanctions in the land use of areas with landslides risk. The policy sanction must be preceded by the socialization of the spatial planning settlements, including the rules and legal sanctions for those who violate them, the extension of public awareness, the development of capacity of law enforcement resource, and the promotion of preventive efforts in order to prevent the activities of land uses which are not according to the alternative policies in form of socialization about land use plan for settlement in areas with landslides risk.

\section{Strengthening the Slope Vegetatively in Areas with Landslides Risk in Palupuah Subdistrict, Agam Regency}

The steps for the implementation of the alternative policies of landslide area mitigation and adaptation in Palupuah Subdistrict, Agam Regency are: (1) optimizing the use of broad-leaved plants and roots riding as the natural canopy for the ground beneath. The natural canopy serves to hold the rain water drops so the kinetic energy can be reduced, (2) applying the soil conservation techniques with reforestation, and (3) doing the agroforestry at the foot slopes.

\section{Strengthening the Slope Mechanically in Areas with Landslides Risk in Palupuah Subdistrict, Agam Regency}

The steps for the implementation of the alternative policies of landslide area mitigation and adaptation in Palupuah Subdistrict, Agam Regency are: (1) controlling the surface water flow to higher land with horizontal or vertical drain, (2) enhancing the drainage along the road, and (3) performing soil reinforcement such as Gabion Wall, Crib Wall and Soil nailing.

Developing Land Allotment Landslides Based in Areas with Landslides Risk in Palupuah Subdistrict, Agam Regency

The steps for the implementation of the alternative policies of landslide area mitigation and adaptation in Palupuah Subdistrict, Agam Regency are: (1) preparing and formulating the zones for land use, (2) doing the firm and consistent supervision and control for each zone land use, and (3) involving the society actively in areas with landslides risk improvement, education, and socialization activities. The society 
involvement should be started from the designing the land use zones, formulating the socialization programs and surveillance of land use.

\section{The Implications of the Alternative Policies of Landslide Area Mitigation and Adaptation in Palupuah} Subdistrict, Agam Regency

The results of research establish the alternative policy priorities of landslide area mitigation and adaptation in Palupuah Subdistrict, Agam Regency and the implementations. The results of analysis of this research are the four alternatives policy priorities with various implementation strategies that will be able to answer the expectations and objectives of landslide mitigation applications Palupuah Subdistrict, Agam Regency, West Sumatra Province. The implications need the commitment of the subdistrict and district government, private companies, and the society to apply the the alternative policy priorities of landslide area mitigation and adaptation. The government of subdistrict and district should be consistent and continually provide the guidance in the land use, especially for the settlements in areas with landslides risk in Palupuah Subdistrict, Agam Regency, West Sumatra Province. The efforts that should be done are: (1) developing technical standards, technical guidelines, zones regulation and manual for reference of the settlements in areas with landslides risk, (2) establishing the management, training, and technical assistance in applying the techniques to strengthen the slope vegetatively and mechanically, (3) establishing the mechanism of sanctions and rewards for violation of land use of areas with landslides risk, (4) providing the guidance and technical assistance for the government district and village against the dangers of the areas with landslides risk, and (5) implementing the legal provisions related to the land use which should not be used.

\section{The Alternative Policies of Landslide Area Mitigation and Adaptation in Palupuah Subdistrict, Agam} Regency

Based on the results of research, the alternative policies of landslide area mitigation and adaptation obtained are: (1) conducting the settlements management in areas with landslides risk, (2) strengthening the slope vegetatively, (3) strengthening the slope mechanically, and (3) developing land allotment landslides based.

\begin{tabular}{|l|l|}
\hline 1 & Planting the annual taproot plants in the slope area \\
\hline 2 & Avoiding building houses on the steep slope area \\
\hline 3 & Creating the sewerage in the water cycle area \\
\hline 4 & Making the rules based on the local wisdoms that respond to the landslide \\
\hline 5 & Checking the slope peak if rain occur for a long period \\
\hline 6 & Leveling the slope on the crowded settlement area \\
\hline 7 & Performing the agricultural pattern landslide mitigation based \\
\hline
\end{tabular}

The formulation of alternative policy directions adaptation of landslides are: 1) planting the annual taproot plants in the slope area, 2) avoiding building houses on the steep slope area, 3) creating the sewerage in the water cycle area, 4) making the rules based on the local wisdoms that respond to the landslide, 5) checking the slope peak if rain occur for a long period, 6) leveling the slope on the crowded settlement area, and 7) performing the agricultural pattern landslide mitigation based.

\section{Conclusion}

The results and discussion of the alternative policies of landslide area mitigation in Palupuah Subdistrict, Agam Regency, West Sumatra Province, Indonesia are: (1) conducting the settlements management in areas with landslides risk of the greatest weight rated $(0,795)$, (2) strengthening the slope vegetatively (0.792), (3) strengthening the slope mechanically (0.769), and (4) developing land allotment landslides based (0.750). The alternative policies of landslide area adaptation in Palupuah Subdistrict, Agam 
Regency, West Sumatra Province, Indonesia are: (1) avoiding building houses in the steep slopes area, (2) performing the agricultural pattern landslide mitigation based, (3) creating the sewerage in the water cycle area, and (4) making the rules based on the local wisdoms that respond to the landslide.

\section{Reference}

Biswajeet, P., S. Mansor, S. Lee, and M. F Buchroithner (2008). Application of A Data Mining Model for Landslide Hazard Mapping, vol. XXXVII, Part B8, Beijing.

Carrara, A, M Cardinali, , and F Guszzaetti (1992). Uncertaintly in Assesing Landslide Hazzard and Disk. ITC Jurnal. Vol. 2: 172-182

Destriani, Novia, and A. Pamungkas. (2013) Identifikasi Daerah Kawasan Rentan Tanah Longsor dalam KSN Gunung Merapi di Kabupaten Sleman. Program Studi Perencanaan Wilayah dan Kota, Fakultas Teknik Sipil dan Perencanaan Institut Teknologi Sepuluh Nopember (ITS) Jurnal Teknik Pomits, Vol. 2, No. 2

Dibyosaputro. (1998). Geomorfology Dasar, Universitas Gajah Mada, Yogyakarta

Javier H and P.L Rosin. (1996). Landslide Mapping by Textural Analysis of Atm Data, Institute for Remote Sensing Applications 21020 Ispra (Va), Italy

Hermon, D. (2009). Dinamika Permukiman dan Arahan Kebijakan Pengembangan Permukiman pada Kawasan Rawan Longsor di Kota Padang Sumatera Barat. Disertation, Institut Pertanian Bogor. Bogor

Hermon, D. (2012). Mitigasi Bencana Hidrometeorologi Banjir, Longsor, Ekologi, Degradasi Lahan, Putting Beliung, Kekeringan, UNP Press, Padang

Hermon dan Triyatn. (2005). Analisis Spasial Bahaya dan Risiko Longsor Lahan di Gunung Padang Sumatera Barat, FIS UNP, Padang

Lilik, K. (2008). Kajian Penilaian Bahaya Longsor Provinsi Sumatera Utara, Pusat Tekhnologi Sumber Daya Lahan. Jurnal Sains dan Tekhnologi Indonesia. Vol 1: 90-98

Mardianto, D. (2001). Risiko Longsor Di Kecamatan Girimulyo. Kabupaten Kulon Progo. Daerah Istimewa Yogyakarta. Thesis, Universitas Gadjah Mada, Yogyakarta

Marsaid. (2002). Kebijakan Pemerintah Kabupaten Purworejo dalam Penanggulangan Bencana Alam Tanah Longsor. Paper in Simposium Nasional Pencegahan Bencana Sendimen. Kerjasama ISDM, JICA,DIRJEN Sumberdaya Air, Yogyakarta, pp 50 -58

Nursa'ban, Sagiharyanto and K. Nurul. (2010). Pengukuran Kerentanan Longsorlahan Sebagai Upaya Mitigasi Bencana di Perbukitan Menoreh. Jurnal Penelitian Saintek. Vol. 15

Randall W J., and D. K Keefer. (1988). Statistical Analysis of Factors Affecting Landslide Distribution in The New Madrid Seismic Zone, Tennessee and Kentucky. U.S. Geological Survey, Reston, VA 2209.2 (U.S.A.), U.S. Geological Survey, Menlo Park, California 94025 (U.S.A.)

Sutikno. (2001). Gempa Bumi dan Agihanya di Indonesia, Upaya Meminimalisi Kerugian Akibat Gempa Bumi Pada Rumah Sederhana. Makalah Teknik Sipil, April $21^{\text {st }} 2001$, Surabaya

Triyatno. (2001). Studi Tingkat Bahaya dan Longsoran di Daerah Ngarai Sianok Kota Bukittinggi Sumbar, Universitas Gajah Mada

Triyatno. (2004). Study Tingkat Bahaya dan Risko Longsoran di Daerah Ngarai Sianok Kota Bukittinggi Sumbar, Universitas Gajah Mada

Olivia Oktorie (October 17, 1990) Born in Bukitinggi, West Sumatra, Indonesia. Master graduate of Geography Education, Faculty of Social Sciences, Universitas Negeri Padang, Indonesia (2016). Active as an environmental and disaster researcher at the Center for Disaster and Environmental Studies, and the Center for Population and Aspiration Studies of the Community, Master of Geography Education Program, Universitas Negeri Padang, Indonesia 